\title{
Intermetallics: past, present and future
}

\author{
D.G. Morris* and M.A. Muñoz-Morris*
}

\begin{abstract}
Intermetallics have seen extensive world-wide attention over the past decades. For the most part these studies have examined multi-phase aluminide based alloys, because of their high stiffness, combined with reasonable strength and ductility, good structural stability and oxidation resistance, and attempted to improve current $\mathrm{Ni}$-base superalloys, $\mathrm{Ti}$-base alloys, or Fe-base stainless steels for structural aerospace applications. The current status of development and application of such materials is briefly reviewed. Future developments are taking intermetallics from the realm of "improved high-temperature but low-ductility metallic alloys" into the realm of "improved aggressive-environment, high-toughness ceramic-like alloys". Such evolution will be outlined.
\end{abstract}

Keywords Intermetallics. Ni-base. Fe-base and Ti-base intermetallic compounds. High temperature strength. Aerospace applications.

\section{Intermetálicos: pasado, presente y futuro}

\begin{abstract}
Resumen Durante los últimos décadas ha habido un desarrollo de los intermetálicos, sobre todo por aplicaciones estructurales a alta temperatura en aplicaciones aeroespaciales, donde, por su rigidez alta, en combinación con una resistencia mecánica y ductilidad razonable, su buena estabilidad estructural y resistencia a la oxidación, han sido vistos como versiones avanzadas y mejoradas de las aleaciones metálicas como, por ejemplo, las superaleaciones a base de nitrógeno y las aleaciones de titanio. Se discute el desarrollo importante durante las últimas décadas, y también los nuevos desarrollos probables durante los próximos años. Se podrían ver los intermetálicos como versiones mejoradas de los cerámicos.
\end{abstract}

Palabras clave Intermetálicos. Compuestos intermetálicos a base de nitrógeno, hierro o titanio.

Resistencia a alta temperatura. Aplicaciones aeroespaciales.

\section{INTRODUCTION}

Intermetallics are materials with an ordered arrangement of mixed atom species of metal-metal or metal-semimetal types, generally in a nearstoichiometric composition, for example $\mathrm{Ni}_{3} \mathrm{Al}$, $\mathrm{FeAl}, \mathrm{TiAl}, \mathrm{MoSi}_{2}$, etc. Here nickel (Ni), iron $(\mathrm{Fe})$, titanium $(\mathrm{Ti})$ and molybdenum $(\mathrm{Mo})$ play the role of metal and aluminium $(\mathrm{Al})$ or silicon $(\mathrm{Si})$ the role of metal/semimetal. In such cases the metal-metal or metal-semimetal bonding takes on a partially metallic and partially covalent (or ionic) nature. There are also important intermetallic compounds of metal-metal combinations where atomic size differences are responsible for the ordered arrangement, notably for the Laves phases. The existence of strong interatomic bonding leads to higher elastic moduli -stiffer materials. The presence of a reactive species, aluminium or silicon here, leads to the formation of a protective surface layer which endows good oxidation and corrosion resistance. The ordered superlattice structure means that larger shear displacements are required to plastically deform the lattices, and these may not be found in atomically-smooth slip planes, leading generally to stronger, less ductile materials. These essential characteristics have led to the interest in intermetallic compounds as stiff and strong, oxidation-resisting materials for aerospace structural applications.

Based on such promise, considerable effort has been devoted to the development of intermetallics as aerospace materials. While showing good strength and environmental stability, other aspects such as low ductility and toughness and mediocre creep strength, as well as fabrication difficulties

(*) Department of Physical Metallurgy, CENIM-CSIC, Avda. Gregorio del Amo 8, 28040 Madrid, Spain. 
have greatly hindered the introduction of intermetallics as industrial structural materials. The present document gives a very short account of the major research and development activities that have taken place over the past few decades, to the present time, and also gives some indications of where future activities may lead. The document considers in turn the evolution and activities corresponding to each of the most important families of intermetallic compounds.

\section{2. $\mathrm{Ni}_{3} \mathrm{Al}$ ALLOYS}

Basic studies over the 1980-1990 decade offered the hope that the brittle stoichiometric intermetallic could be transformed into a useful, ductile material by micro-alloying (additions of $\mathrm{B}$ to enhance grain boundary strength) or by macroalloying (excess $\mathrm{Ni}$ to avoid the stoichiometric composition; $\mathrm{Cr}$ addition to avoid intermediate temperature embrittlement). These materials, with a higher $\mathrm{Al}$ content than conventional superalloys, would have lower density and higher melting point, and would lead to improved versions of such superalloys. This research came to an abrupt halt when it was realised that the creep strength was poor, and possibilities of use as an aerospace material were limited.

Despite this "loss of limelight", $\mathrm{Ni}_{3} \mathrm{Al}$-base alloys have been developed into commercial materials of some considerable value - notably as new high temperature alloys where shorter-term strength, rather than creep strength, is the important property (e.g. forging or extrusion dies; superalloy-competing materials for aerospace components) ${ }^{[1]}$, and also as materials resisting aggressive chemical and mechanical environments (material-processing rolls; sulphur-rich oil well piping) ${ }^{[2]}$.

\section{3. $\mathrm{Fe}_{\mathrm{x}} \mathrm{Al}$ ALLOYS}

Basic alloy studies over the 1980-1990 decade showed that neither $\mathrm{Fe}_{3} \mathrm{Al}$ based alloys nor $\mathrm{FeAl}$ based alloys possessed good high temperature strength, and aerospace interest quickly ceased. Work continued, especially at Oak Ridge National Laboratory, on the development of more ductile and creep-resisting $\mathrm{Fe}_{3} \mathrm{Al}$ base alloys as substitute alloys for conventional high-temperature and stainless steels - by micro-alloying additions (such as $\mathrm{B}, \mathrm{Cr}, \mathrm{Nb}, \mathrm{Mo}$, etc.) and by microstructure control (grain size and aspect ratio...).
Difficulties of processing these $\mathrm{Fe}_{3} \mathrm{Al}$ based materials, and their minimum property advantages over already existing steels, led to a halt to this research, and a subsequent attention to $\mathrm{FeAl}$ base alloys of higher oxidation-resisting capacity.

While most development work has now stopped, one US company has recently announced the commercialisation of $\mathrm{FeAl}$ strip, prepared by powder metallurgy methods, and used for hightemperature heating elements ${ }^{[3]}$. Additionally, a current EU project is evaluating the industrialscale processing of high strength, ductile $\mathrm{FeAl}$, also using powder metallurgical methods ${ }^{[4]}$.

\section{TiAI ALLOYS}

This is the intermetallic family that has received the most attention, continuing to the present. Some of the major advances are presented in volumes such as those of references ${ }^{[5-7]}$. A very brief outline of developments over the past decades is given below:

- 1980-1990:

Identification of $\mathrm{TiAl}$ as most important potential aerospace intermetallic. Realization that a two-phase mixture composed of $\mathrm{a}_{2}$ and $\mathrm{g}$ phases $\left(\mathrm{Ti}_{3} \mathrm{Al}\right.$ and $\mathrm{TiAl}$ phases) is the best structural material. Examination of the role of chemical composition modifications (amount of Al, additions of $\mathrm{Nb}, \mathrm{Cr}, \mathrm{Mn}, \mathrm{V}$, etc.) evaluated to balance mechanical and chemical (oxidation) behaviour.

- 1990-1995:

Development of "first-generation" alloys based on 48-2-2 (48\% Al with $2 \% \mathrm{Nb}$ and $2 \% \mathrm{Cr}$ or $\mathrm{Mn}$, etc.) with good balance of mechanical properties and oxidation resistance. Identification of turbocharger rotors and valves in automobile engines, as well as aero- and land-based-turbine blades and valves as important components where these materials should be used.

Cast structures being coarse, the examination of $B$ additions to the melt to obtain refined assolidified structures - the development of the German TAB alloys.

Development of casting techniques for producing aerospace and land-base (powergenerating) turbine blades and vanes. 
Development of techniques for rolling thin sheets of TiAl (based on "pack-rolling" methods), superplastic forming techniques, joining processes.

\section{- 1995-2000:}

Development of cast technologies for clean and contaminant-free ingot production - is no easy task for such high melting point and highly reactive alloys.

Development of more complex alloys, for example as Ti-Al-M1-M2-SM: where the Al content may be reduced slightly towards $44 \%$ to allow more of the strong $a_{2}$ phase to be retained, $\mathrm{M} 1$ is a transition metal such as $\mathrm{Cr}, \mathrm{Mn}, \mathrm{V}$ introduced to control ductility, M2 is an early bcc metal such as $\mathrm{Nb}, \mathrm{Ta}, \mathrm{Mo}, \mathrm{W}$, etc, used to improve creep and oxidation characteristics, and SM is a semi-metal such as $\mathrm{Si}, \mathrm{B}, \mathrm{C}$, etc, used to improve creep behaviour.

Examination of segregation problems during cast - which can be very severe, with as much as \pm $2-3 \% \mathrm{Al}$ variation as macrosegregation in a $\mathrm{Ti}-48$ $\% \mathrm{Al}$ alloy base.

Development of processing procedure for production of automobile valves - based on clean ingot casting, bar extrusion, heavy working to valve head form. A comparative evaluation of powder metallurgy techniques for the same components.

Development of cast-HIP-extrusion-forging processing for the preparation of turbine blades. Comparative development of powder processing, either directly to HIP-forged blades, or as precursors to sheet rolling and then diffusion bonding to hollow blades.

Upscale of casting techniques to pilot-scale production quantities.

Development of friction welding/laser welding techniques and the introduction of cast, bondedshaft turbocharger rotors to industrial production.

- 2000-2005:

Development of stronger higher-temperature alloys, for example the higher $\mathrm{Nb}$ alloys, $\mathrm{TNB}$, of composition $\mathrm{Ti}-(44-47 \%) \mathrm{Al}-(5-10 \% \mathrm{Nb})-(1-3$ \%)M1-(0.5-1\%)SM, where M1 is an element such as $\mathrm{Cr}, \mathrm{Ta}, \mathrm{Mo}, \mathrm{W}$ etc, and SM is an element such as $\mathrm{B}, \mathrm{Si}, \mathrm{C}$.

Pilot plant-scale casting of $\mathrm{TiAl}$ for automobile applications.
Test introduction of cast-forged TNB blades/vanes for high-pressure compressors in aeroturbines (Germany-UK).

Low temperature turbine blades by powder metallurgy-HIP processing (France).

Cast turbochargers rotors for automobiles (Japan - Daido/Toyota/Mitsubishi).

Over the past decades there has been a clear evolution from basic research into structure, microstructure and property relationships, combined with suggestions for "first-generation" alloy compositions, towards a balance of process examination, development and scale-up while more sophisticated alloy compositions and structures are produced. As the first, relatively small-scale applications begin, it should be remembered that these gamma-aluminide alloys are still relative "youngsters" in their materials field, having been around for only 15 years or so, while their serious competitor, the Ni-base superalloy, is well installed and has been optimised by 60 years or so of research, development and production.

\section{FUTURE DEVELOPMENTS}

As outlined above, extensive development of $\mathrm{Ni}_{3} \mathrm{Al}, \mathrm{FeAl}$ and, especially, of TiAl is almost completed, and these materials are now slowly gaining acceptance as they start to be used as commercial materials.

Research is now underway on several new versions of intermetallics, where it appears that two families may receive attention - $\mathrm{Fe}_{\mathrm{x}} \mathrm{Al}$-base alloys and Silicides of bcc transition metals such as $\mathrm{Mo}, \mathrm{Nb}$. In both cases, it is the important industrial demand for materials capable of supporting higher temperatures in very aggressive environments that is important. Iron aluminide alloys - read as Al-rich Fe-base steels - have outstanding environmental resistance behaviours in a wide range of industrial environments, including sulphidising, carburising, and oxidising conditions. This industrial demand is leading to significant research and development activity, including via mechanical alloying, alloy composition control, and processing studies. Molybdenum silicides (based essentially on the $\mathrm{MoSi}_{2}$ compound) are widely used in the heat treatment industries, for their good oxidation resistance, but have too low toughness and suffer low-temperature "PEST" degradation to find wider use as structural materials. Significant research 
activity on alloy composition and microstructural modification, and on processing method, is taking place, including extensive activity on multi-phase alloys based on the $\mathrm{MoSi}_{2}-\mathrm{Mo}-\mathrm{Mo}_{3} \mathrm{Si}-\mathrm{Mo}_{5} \mathrm{SiB}_{2}$ system. The window being addressed here is of very high-temperature and very aggressive (oxidising) environments, with improved fabricability and toughness/fatigue behaviour over that found in the competing ceramic-base materials.

\section{Acknowledgements}

We should like to make special acknowledgement to the very many colleagues who have helped us with the provision of information and examples for this presentation (with apologies to those we may have neglected to thank): R Cahn (Cambridge), S.C. Deevi (Philip Morris USA), E.A. Ford (Mater. Tech. Inst.), Y-W. Kim (UES), D.L. Lin (Shanghai), C.T. Liu, C. McKamey, J. Schneibel and V.K. Sikka (ORNL), M. Loretto (Birmingham), S. Naka and M. Thomas (ONERA), M. Palm and G. Sauthoff (MPI, Dusseldorf), M. Yamaguchi (Kyoto).

\section{REFERENCES}

[1] D.L. Lin, C.T. LiU and S.L. SASS (Eds.), Proc. $3^{\text {rd }}$ Int. Workshop on "Ordered Intermetallic Alloys and Composites", Hangzhou, China, 1998; Trans. Non-Ferrous Met. Soc. China 9 (1999).

[2] V.K. SikKa, S.C. DeEvi, S. Viswanathan, R.W. Swindeman and M.L. SAntella, Proc. ASM Conf. "Intermetallics for the Third Millennium”, S.C. Deevi, C.T. Liu and M. Yamaguchi (Eds.), 1999; Intermetallics 8 (2000) 1329.

[3] M.R. Hajaligol, S.C. Deevi, V.K. SikKa and C.R. Scorey, Proc. TMS Conf. "Iron Aluminides: Alloy Design, Processing, Properties and Applications", S.C. Deevi, D.G. Morris, V.K. Sikka and J.H. Schneibel (Eds.), 1998; Mater. Sci. Eng. A 258 (1998) 249.

[4] "Light weight FeAl intermetallic alloy for high efficiency components in transportation and power generation industries", EU GROWTH project: FIAC.

[5] D.G. Morris, S. NAKA and P. Caron (Eds.), Proc. of EUROMAT 99 Conf. "Intermetallics and Superalloys", Munich, 1999; Wiley-VCH, Weinhein, 2000.

[6] K.J. Hemker, D.M. Dimiduk, H. Clemens, R. Darolia, H. INUI, J.M. LARSEN, V.K. SiKKA, M. ThOMAS and J.D. Whittenberger (Eds.), Proc. Int. Conf. "Structural Intermetallics 2001", Jackson Hole, Wyoming, TMS, Warrendale, 2001.

[7] "Titanium-Aluminide-Alloys", Project Review, PTJ-NMT, Jülich, Germany, 2003. 